\title{
Phytolith-occluded carbon sequestration potential in three major steppe types along a precipitation gradient in Northern China
}

\author{
Qi Limin ${ }^{1}$, Sun Tingyu ${ }^{1}$, Guo Xudong ${ }^{1}$, Guo Ying ${ }^{1}$, and Frank Li $^{1}$ \\ ${ }^{1}$ Inner Mongolia University
}

July 25,2020

\begin{abstract}
Phytolith-occluded carbon (PhytOC) is an important long-term stable carbon fraction in grassland ecosystems, and plays a promising role in global carbon sequestration. Determination of the PhytOC traits of different plants in major grassland types is crucial for precisely assessing their PhytOC sequestration potential. Precipitation is the predominant factor in controlling net primary productivity (NPP) and species composition of the semiarid steppe grasslands. We selected three representative steppe communities of desert steppe, dry typical steppe and wet typical steppe in Northern Grasslands of China along a precipitation gradient, to investigate their species composition, biomass production and PhytOC content for quantifying its long-term carbon sequestration potential. Our results showed that (i) the phytolith and PhytOC contents in plants differed significantly among species, with dominant grass and sedge species having relatively high contents, and the contents are significantly higher in below- than the aboveground parts. (ii) The phytolith contents of plant communities were 16.68, 17.94 and $15.85 \mathrm{~g} \mathrm{kg-1} \mathrm{in}$ the above- and $85.44,58.73$ and $76.94 \mathrm{~g} \mathrm{kg-1}$ in the belowground biomass of desert steppe, dry typical steppe and wet typical steppe, respectively; and the PhytOC contents were $0.68,0.48$ and $0.59 \mathrm{~g} \mathrm{~kg}-1$ in the above- and $1.11,0.72$ and $1.02 \mathrm{~g} \mathrm{kg-1}$ in the belowground biomass of the three steppe types. (iii) Climatic factors affected phytolith and PhytOC production of steppe communities mainly through altering plant production, whereas their effects on phytolith and PhytOC contents were relatively small. Plant aboveground biomass and PhytOC content were strongly associated with the current-year climate and soil bio-available Si content; while plant belowground biomass and PhytOC content were relatively stable, and their variation across the sites is in accordance with the spatial variation in the long-term means of climatic and soil factors, reflecting the perenniality of plant belowground part.
\end{abstract}

\section{INTRODUCTION}

Climate warming and the increase of extreme climatic events are mostly attributed to the increasing concentrations of greenhouse gases in the atmosphere, especially carbon dioxide $\left(\mathrm{CO}_{2}\right)$. The coupled biogeochemical cycles of carbon $(\mathrm{C})$ and silicon $(\mathrm{Si})$ in the terrestrial system are deemed a mechanism that impacts the longterm regulation of atmospheric $\mathrm{CO}_{2}$ (Berner, 1992; Parr et al., 2010; Parr \& Sullivan, 2011; Song et al., 2012a; Song et al., 2012b). Plants absorb mono-silicic acid from soil solution via their roots (Epstein, 1994; Ma \& Yamaji, 2006) and deposit silica $\left(\mathrm{SiO}_{2}\right)$ in plant tissues as phytoliths (Hodson et al., 2005; Schaller et al., 2013). Approximately $0.1 \%-6.0 \%$ organic $\mathrm{C}$ in plants is reported to be incorporated in phytoliths during their formation, and is referred to as phytolith-occluded carbon (PhyOC) (Bartoli \& Wilding, 1989; Jones \& Milne, 1965; Zuo \& Lü, 2011). Phytoliths exist in most plants, and their content in plant tissues varies among plant species, ranging from less than $0.5 \%$ in most dicotyledons, $1 \%-3 \%$ in dryland grasses, and up to 10\%-15\% in the Cyperaceae and wetland Poaceae species (Epstein, 1994). Phytoliths are mainly deposited in the cell wall, cell lumen and intercellular spaces or the extracellular layer in plant issues (Epstein, 2009; Hodson et al., 2005; Ma \& Yamaji, 2006; Schaller et al., 2013); after plants' death, the phytoliths can be incorporated into soil or sediments after the decomposition of plant litter (Blecker et al., 2006). Since phytoliths are resistant to decomposition, PhytOC can be preserved in soil or sediments with the Si-coat 
protection for several hundred or thousand years, and may account for $82 \%$ of the total organic carbon in some old soils (Parr \& Sullivan, 2005; Song et al., 2017). The formation and stability of PhytOC in the coupled biogeochemical cycling of $\mathrm{C}$ and $\mathrm{Si}$ has been increasingly recognized as a promising mechanism of terrestrial ecosystems to sequester atmospheric $\mathrm{CO}_{2}$, which has motivated many researchers to quantify the PhytOC sequestration potential of various systems (Parr et al., 2010; Parr \& Sullivan, 2011; Song et al., 2012a).

Grasslands are an important terrestrial ecosystem covering more than one-fifth of the world's land surface (Scurlock \& Hall, 2010). The large distribution area and the high PhytOC concentration in grassland plants, especially Poaceae and Cyperaceae species (Epstein, 1994; Clarkson \& Hanson, 1980), make grassland a particularly important long-term C sequestration process (Blecker et al., 2006; Song et al., 2017). Several studies assessed the PhytOC sequestration potential of grasslands (Pan et al., 2017; Qi et al., 2016; Song et al., 2012a). Song et al. (2012a) reported that phytolith and PhytOC production rates in aboveground biomass of grassland were significantly influenced by their aboveground net primary productivity (ANPP); Qi et al. (2016) suggested that the belowground productivity of plants could play a dominant role in PhytOC production in grassland ecosystems; and Ji et al. (2018) reported that Si distribution in the aboveground parts, thus the PhytOC sequestration potential, of grassland plants, varies markedly among plant species and across grassland types. However, the effects of grassland type and species composition on the production rate of phytoliths and PhytOC (including the above- and belowground parts) are still not fully understood. Precipitation is the predominant climatic factor that controls plant species composition and net primary productivity (NPP) of grassland ecosystems in semi-arid steppe region (Bai et al., 2004; Dai et al., 2012; Hou et al., 2014), thus affecting the PhytOC sequestration potential. As such, it is necessary to investigate the PhytOC production rate in different grassland types along climatic gradient, for accurate estimation of PhytOC sequestration potential and prediction of their response to climate changes. In present study, we selected three representative vegetation types in climatically different regions alone a precipitation gradient in Inner Mongolia, that is, the desert steppe, the dry typical steppe, and the wet typical steppe regions, to study their PhytOC production. Specifically, we aimed to investigate the species composition, and measure the phytolith and PhytOC contents of the major plant species, of these grassland types, so as to increase the accuracy in estimating phytoliths and PhytOC production and storage in plant communities, and analyze their relations with climatic factors. We hypothesized that along the gradient of climate aridity increase (that is, precipitation decrease) from the wet dry steppe site, via the dry typical steppe site to the desert steppe site, the grassland NPP would decrease, while the contents of phytoliths and PhytOC in the steppe plants would increase due to the intense plant transpiration but low biomass production.

\section{MATERIALS AND METHODS}

\subsection{Sampling sites}

This study was conducted at three sites in the steppe region of central Inner Mongolia along a climatic gradient of increasing annual precipitation, that is, at a desert steppe site (within Sunite Right Banner, at $43^{\circ} 511^{\prime} \mathrm{N}, 113^{\circ} 42^{\prime} \mathrm{E}$ ), a dry typical steppe site (within Maodeng farm of Xilinhot city, at $44^{\circ} 50^{\prime} \mathrm{N}, 116^{\circ} 36^{\prime} \mathrm{E}$ ), and a wet typical steppe site (within West Ujimqin Banner, at $45^{\circ} 43^{\prime} \mathrm{N}, 118^{\circ} 30^{\prime} \mathrm{E}$ ). The region experiences a temperate semiarid climate. The mean annual temperature (MAT) are -0.9, 2.9 and 4.9, and mean annual precipitation (MAP) are 182, 278 and $342 \mathrm{~mm}$, respectively at the desert steppe, dry typical steppe and wet typical steppe sites; and 75\%-85\% of annual precipitation falls in the plant growing seasons from May to September (average of the 1960-2016 period). In the year for field study (2016), the annual precipitation was 189, 309 and $299 \mathrm{~mm}$, and the plant growing-season precipitation was 129, 215 and $237 \mathrm{~mm}$, respectively in the desert steppe, dry typical steppe and wet typical steppe sites. The desert steppe site is on a calcic brown soil, whereas the other two steppe sites are on chestnut soil. The humus layer is $15-30 \mathrm{~cm}$ in depth, and the calcic horizon (mostly $\mathrm{CaCO}_{3}$ ) is 30-60 $\mathrm{cm}$ in depth, both increasing from desert steppe to dry typical steppe and wet typical steppe. The dominant species of the vegetation are Stipa klemenzii, Cleistogenes songorica, Allium bidentatum and Salsola collina in the desert steppe, Leymus chinensis, Stipa kryloviiand Cleistogenes squarrosa in the dry typical steppe, andLeymus chinensis, Stipa grandis and Cleistogenes squarrosain the 
wet typical steppe (Table 2).

\subsection{Field sampling}

All the three sampling sites were located on flat ground with representative native steppe communities. The sites were fenced to exclude animal grazing at the beginning of the plant growing season in 2016, and plant and soil samples were collected from these sites at the end of August. At each site, five quadrates of $1 \mathrm{~m} \times 1 \mathrm{~m}$ were set up at the center and four corners of a delineated area of $20 \mathrm{mx} 20 \mathrm{~m}$, and all standing live and dead vascular plants (that was obviously produced during the current season) in these quadrats were harvested at ground level species by species, dried to a constant weight at 65 and weighed. The dry mass of all plant species per quadrat averaged over five replicates was used to determine the aboveground plant biomass at peak plant biomass time, and this was also used to approximate ANPP of the grassland (Scurlock et al., 2002). The belowground biomass and its distribution profile $(0-70 \mathrm{~cm})$ were measured using the soil coring method, and BNPP (during the plant growing season from May to October) of the studied grassland was obtained from previous studies (Chai et al., 2014; Hou et al., 2014).

Whole plants of dominant species at each site were collected by digging up each individual to a depth of $20 \mathrm{~cm}$ below ground level, and then each individual was cut into two parts: aboveground part (shoots) and belowground part (noted as roots, but it includes plant roots and rhizomes as well as shoot stumps buried below the soil surface). A sample of about $300 \mathrm{~g}$ dry matter of the shoots and the roots of each plant species was collected in each of the three plots at each site. The samples were washed with deionized water, dried at 65 and then cut into pieces $(<5 \mathrm{~mm})$ for phytolith analysis.

The soil bulk density and moisture content were obtained by the cutting-ring method and the oven drying method (at 105). The soil samples were collected using soil cores (diameter $=7 \mathrm{~cm}$ ) and air dried at ambient temperature in laboratory.

\subsection{Sample analysis}

The phytoliths within plant parts were extracted using a microwave digestion process (Parr et al., 2001) followed by a Walk-Black type digestion to ensure the purity of the phytoliths (Parr \& Sullivan, 2014; Walkley $\&$ Black, 1934). Two duplicates were analyzed for each plant sample. The exacted phytoliths were dried at 65 to a constant weight. The PhytOC was determined using the PhytOC alkalidis solution spectrophotometer method (Yang et al., 2014). In this method, sodium hydroxide solution was used to dissolve the $\mathrm{Si}$ compound in order to release the occluded organic carbon from the phytoliths, then potassium dichromate $\left(\mathrm{K}_{2} \mathrm{Cr}_{2} \mathrm{O}_{7}\right)$-sulfuric acid $\left(\mathrm{H}_{2} \mathrm{SO}_{4}\right)$ solution was used to oxidize the released organic carbon, and the concentration of $\mathrm{Gr}^{3+}$ produced in this oxidation was determined by spectrophotometer with its absorbance at $590 \mathrm{~mm}$ wavelength. The organic carbon concentration was calculated based on the amounts of potassium dichromate consumed, and the accuracy and repeatability of the method was well verified against the results obtained with acid dissolution-Elementar Vario MAX CN method (Germany) (Yang et al., 2014). The phytoliths and PhytOC contents of the two parts of each plant species were calculated as the average of the three replicate plots. For each species, the ratio of aboveground to belowground biomass (shoots/roots) was calculated based on the sampled plant individuals. The ratio was used to calculate the belowground biomass of the species in $1 \mathrm{~m}^{2}$ based on the measured aboveground biomass of the species. The estimation of plant root biomass in the soil profile and the turn-over rate of the belowground biomass were quoted from previous studies (Chai et al., 2014; Hou et al., 2014).

The air dried soil samples were separated into the 100 mesh soil samples and the 10 mesh soil samples. The soil organic carbon (SOC) was determined with the 100 mesh soil samples using the method of classical potassium dichromate (Walkley \& Black, 1934), and the soil $\mathrm{pH}$ and bioavailable Si content were analyzed with 10 mesh soil samples using a pH meter (Yang et al., 2018) and silicomolybdic acid method (Yang et al., 2018), respectively.

\subsection{Data calculations and statistics}

The formula for calculating phytolith and PhytOC contents in plant species were as follows: 
phytolith content $\left(\mathrm{g} \mathrm{kg}^{-1}\right)=$ phytolith weight $(\mathrm{g}) /$ dry biomass $(\mathrm{kg})[1]$

PhytOC content $\left(\mathrm{g} \mathrm{kg}^{-1}\right)=$ PhytOC weight $(\mathrm{g}) /$ dry biomass $(\mathrm{kg})[2]$

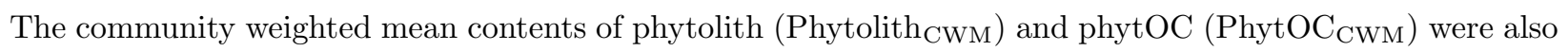
calculated using biomass as weight:

phytolith $_{\mathrm{CWM}}\left(\mathrm{g} \mathrm{kg}^{-1}\right)=[?]_{i}$ phytolith content $_{i}\left(\mathrm{~g} \mathrm{~kg}^{-1}\right) \operatorname{xbiomass}_{i}(\%)[3]$

PhytOC $_{\mathrm{CWM}}\left(\mathrm{g} \mathrm{kg}^{-1}\right)=[?]_{i}$ PhytOC content $_{i}\left(\mathrm{gkg}^{-1}\right) \operatorname{xbiomass}_{i}(\%)[4]$

where $i$ enumerates each species.

PhytOC stock $\left(\mathrm{kg} \mathrm{ha}^{-1}\right)=$ PhytOC $_{\mathrm{CWM}}\left(\mathrm{g} \mathrm{kg}^{-1}\right)$ xbiomass $\left(\mathrm{kg} \mathrm{ha}^{-1}\right) \times 10^{-3}[5]$

PhytOC production flux $\left(\mathrm{kg} \mathrm{ha}^{-1} \mathrm{yr}^{-1}\right)=\operatorname{PhytOC}_{\mathrm{CWM}}\left(\mathrm{gkg}^{-1}\right) \mathrm{xNPP}\left(\mathrm{kg} \mathrm{ha}^{-1} \mathrm{yr}^{-1}\right) \mathrm{x}^{-3}[6]$

One-way ANOVA and Duncan's multiple range test were performed to examine the difference in phytolith and PhytOC contents among different parts of plant species. SPSS 20.0 was used for all the statistics and Sigma Plot 12.0 was used for figures.

\section{RESULTS}

\subsection{Soil properties at the three steppe sites}

Soil physical and chemical properties differed among the three sites (Table 1). Soil bulk density was higher in wet typical steppe than other steppes $(P<0.05)$. Soil moisture and the SOC content increased, while soil $\mathrm{pH}$ decreased, from desert steppe to dry typical steppe, and wet typical steppe $(P<0.05)$. The bioavailable Si content in soil showed no significant difference among the three sites.

\subsection{Plant above- and belowground biomass}

Eight, seven and three dominant species were sampled respectively in the desert steppe, dry typical steppe and wet typical steppe communities to determine their phytolith and PhytOC contents; these species contributed to $87.58 \%, 93.65 \%$ and $94.39 \%$ of the aboveground biomass of the three plant communities (Table 2 ). The measured aboveground community biomass were $562.27+-49.28,1471.99+-110.82$ and $1120.09+-$ $52.98 \mathrm{~kg} \mathrm{ha}^{-1}$, and the estimated belowground biomass $(0-70 \mathrm{~cm})$ were $4227.99+-456.20,8639.89+-543.77$ and $8643.74+-491.55 \mathrm{~kg} \mathrm{ha}^{-1}$ in the desert steppe, dry typical steppe and wet typical steppe, respectively. The biomass of major plant species in these communities were shown in Table 3.

\subsection{Phytolith and PhytOC contents in grassland plants}

Phytolith and PhytOC contents in the above- and belowground biomass varied substantially among plant species, and across grassland types (Fig.1, Fig.2). In the aboveground part, the phytolith content was highest in Carex duriuscula $\left(39.96+-2.21 \mathrm{~g} \mathrm{~kg}^{-1}\right)$ and lowest in Salsola collina $\left(4.23+-0.09 \mathrm{~g} \mathrm{~kg}^{-1}\right)$ in desert steppe. The phytolith content in belowground biomass varied from $7.99+-1.34 \mathrm{~g} \mathrm{~kg}^{-1}$ in Salsola collina in desert steppe to $126.0+-9.86 \mathrm{~g} \mathrm{~kg}^{-1}$ in Stipa grandis in wet typical steppe. The PhytOC content in aboveground biomass was in the range of $0.23+-0.06 \mathrm{~g} \mathrm{~kg}^{-1}$ in Salsola collina to $3.63+-0.73 \mathrm{~g} \mathrm{~kg}^{-1}$ in Allium bidentatum in desert steppe; the PhytOC content in belowground biomass was also lowest in Salsola collina $(0.40+-0.13$ $\mathrm{g} \mathrm{kg}^{-1}$ ), but highest inScorzonera divaricata (1.96+-0.09 $\mathrm{g} \mathrm{kg}^{-1}$ ) in desert steppe (Fig.2).

\subsection{Community-weighted mean contents of phytolith and PhytOC}

The community-weight mean phytolith content (phytolith ${ }_{\mathrm{CWM}}$ ) and PhytOC content $\left(\mathrm{PhytOC}_{\mathrm{CWM}}\right)$ in the above- and belowground plant biomass were calculated. As plant belowground biomass was measured at species, not community level, the relative belowground biomass of each species was estimated using the measured relative aboveground biomass (AGB\%) and the shoot/root ratio (A/B) of each species, and used to calculate the community weighted mean phytolith content of belowground biomass. 
The phytolith CwM was $_{16.68}, 17.94$ and $15.85 \mathrm{~g} \mathrm{~kg}^{-1}$ respectively in the aboveground biomass of desert steppe, dry typical steppe and wet typical steppe, no significant difference being detected among the three steppe types $(P>0.05)$; the PhytOC $_{\mathrm{CWM}}$ in the belowground biomass was neither significantly different among the three steppe types $(P>0.05)$, being $86.44,58.73$ and $76.94 \mathrm{~g} \mathrm{~kg}^{-1}$ for the desert steppe, dry typical steppe and wet typical steppe, respectively (Fig.3). The PhytOC ${ }_{\text {CWM was }} 0.68 \mathrm{~g} \mathrm{~kg}^{-1}$ in the aboveground biomass of desert steppe, which was higher than in that of dry typical steppe $\left(0.48 \mathrm{~g} \mathrm{~kg}^{-1}\right)$ or wet typical steppe $\left(0.59 \mathrm{~g} \mathrm{~kg}^{-1}\right)$. The PhytOC $\mathrm{CWM}_{\mathrm{W}}$ in the belowground biomass was $1.11,0.72$ and $1.02 \mathrm{~g} \mathrm{~kg}^{-1}$ respectively in desert steppe, dry typical steppe and wet typical steppe, with no significant difference among these steppes $(P>0.05)$ (Fig.3).

\subsection{The PhytOC sequestration potential and its relations with environmental factors}

The PhytOC stock in the aboveground biomass ranged from $0.38+-0.07$ to $0.71+-0.09 \mathrm{~kg} \mathrm{ha}^{-1}$, and was significantly lower in desert steppe than in two typical steppes $(P<0.05)$; and PhytOC stock in the belowground biomass ranged from $4.67+-0.16$ to $8.79+-0.36 \mathrm{~kg} \mathrm{ha}^{-1}$, and was significantly lower in desert steppe and dry typical steppe than in wet typical steppe $(P<0.05)$ (Table 3$)$.

The PhytOC production flux of steppe communities were estimated based on the NPP and its PhytOC content, and were $0.38,0.71$ and $0.66 \mathrm{~kg} \mathrm{ha}^{-1} \mathrm{yr}^{-1}$ from the aboveground part (ANPP), and 7.88, 9.14 and $21.01 \mathrm{~kg} \mathrm{ha}^{-1} \mathrm{yr}^{-1}$ from the belowground part (BNPP), respectively in the desert steppe, dry typical steppe and wet typical steppe (Table 3 ).

Both plant community aboveground biomass (AGB) and PhytOC content varied significantly across sites; these two plant parameters, and soil bioavailable Si content change synchronously with the current-year annual precipitation (Spearman rank correlation coefficient is 1 among these factors). In contrast, the variation in plant community belowground biomass (BGB) and PhytOC content across sites was more correlated with the long-term mean values of environmental factors, such as mean annual precipitation (MAP) and temperature (MAT), soil bulk density, $\mathrm{pH}$ and SOC content (Spearman rank correlation coefficient is 1 among these factors).

\section{DISSCUSSION}

\subsection{Phytolith and PhytOC contents in grassland ecosystems}

The dominant plant species of grasslands, belonging to Poaceae and Cyperaceae, are Si accumulators (Conley, 2002; Epstein, 1994; Stromberg et al., 2016), and deposit Si mostly in phytoliths (Hodson et al., 2005; Schaller et al., 2013). In the present study, the highest phytolith content in the aboveground parts of plants was detected in Carex duriuscula, a perennial Cyperaceae, whereas the lowest content was inSalsola collina, an annual Chenopodiaceae, consistent with results from other studies (Ru et al., 2018). The highest phytolith content in the belowground parts was detected in Stipa grandis, a perennial bunchgrass, whilst the lowest was also in Salsola collina. Even though a high Si content is not a general feature of monocots (Hodson et al., 2005), many monocots accumulate more Si than non-monocots (Epstein, 1994). In the present study, phytolith contents averaged 22.40 and $57.25 \mathrm{~g} \mathrm{~kg}^{-1}$ respectively in the above- and belowground parts of monocots, higher than that in the above- and belowground parts of dicots, respectively 9.14 and $35.88 \mathrm{~g}$ $\mathrm{kg}^{-1}$.

Both species composition and NPP of plant communities vary substantially along climatic gradient in semiarid regions (Bai et al., 2004; Dai et al., 2012; Hou et al., 2014), whilst the biomass-weighted mean phytolith or PhytOC contents does not show a significant difference among steppe types (Fig. 3). This is because that the dominant species in the studied steppe communities at the three sites are phylogenetically close (i.e., belong to the same genera), thus have similar phytolith or PhytOC contents, and contribute to a large proportion of community biomass. For example, Stipa species are dominants in all the three steppe sites, with their AGB (either of S. klemenzii, S. grandis or S. krylovii) contributing to $45.79 \%, 53.25 \%$ and $48.42 \%$ of the community AGB respectively in the desert steppe, dry typical steppe and wet typical steppe. Also, dominant Cleistogenes songorica or C. squarrosa accounts for $15.59 \%, 9.35 \%$ and $25.04 \%$ of the community 
AGB respectively in these three sites. As a result, the variation in community phytolith or PhytOC contents has much smaller effects on its production flux (= phytolith or PhytOC content x NPP) across the steppe sites, and the variation in phytolith or PhytOC production flux is mainly associated with the changes in NPP. This indicates a predominant role played by plant above- and belowground biomass production along the climate gradient for the phytolith and PhytOC production, which overshadows the effects of the variation in plant PhytOC content at community level.

The significantly higher PhytOC content in the below- than the aboveground biomass, is most likely associated with the perenniality of plants, the PhytOC in the aboveground part is deposited in the current year, whereas that in the belowground part may be deposited in multiple years (Qi et al. 2016). The higher PhytOC content in the aboveground part of desert steppe community than that of typical steppe communities is consistent with our hypothesis that the intense transpiration required for $\mathrm{Si}$ deposition in plant tissues in the desert steppe contributed to the higher PhytOC content. However, the PhytOC production flux is significantly lower in desert steppe community than the typical steppes due to its lower NPP.

The PhytOC content in plants is associated with the silica deposition, thus with the amount of plant $\mathrm{Si}$ uptake (Parr et al., 2009; Li et al., 2013a). The environment factors, such as climate and soil conditions, may influence plant Si uptake, thus the efficiency of PhytOC accumulation in plants (Pan et al., 2017; Li et al., 2013a; Yang et al., 2018). In our study, low pH and high SOC can account for the higher phytolith accumulation in wet than dry typical steppe, which is consistent with the results in previous report (Song et al., 2012b). A higher $\mathrm{pH}$ and moisture content accelerate Si to dissolve in soil solutions (Fraysse et al., 2009; Yang et al., 2018), and to be taken up by plants and transpired in vascular bundles in plants (Epstein, 2009; Parr et al., 2009). Pan et al. (2017) reports that soil $\mathrm{SiO}_{2}$ content shows no significant difference among the grassland sites with different degradation levels, while bioavaliable Si content in the top soil of non-degraded grassland was relatively lower due to more bioavailable Si being absorbed by plants at the site. In studied steppes, the bioavailable Si content in the soil was higher in dry steppe site than in other two sites, which is probably resulted from the less uptake of bioavailable Si from the soil at this site, as its phytolith accumulation was lower than in other two steppe sites.

\subsection{PhytOC long-term sequestration potential}

Many previous studies have assessed the potential of PhytOC sequestration in various ecosystems, such as forest, grassland, wetland and agriculture ecosystems (Parr et al., 2010; Parr et al., 2009; Li et al., 2013b; Zuo et al., 2011). But most of these assessment are based on the PhytOC production in plant aboveground biomass, ignoring that in belowground biomass. A recent study (Chen et al., 2018) reports that the belowground biomass in a bamboo forest accounts for $39.41 \%$ of the total plant biomass.. Another recent study (Zhang et al., 2019) shows that the litter layer in bamboo forest plays a important role as phytOC storage. In native steppes, plant aboveground biomass turns to litter in current year, while the belowground biomass is huge and accumulated over multiple years (Chai, et al., 2014; Dai, et al., 2012; Hou, et al., 2014). Qi et al. (2016) shows that phytOC production from the belowground part is much greater than that from the aboveground parts for the typical steppe. The results of the present study confirms the previous findings with more data from three steppe types along a precitation gradient, and indicate the necessity to involve the belowground part in the assessment of PhytOC production and sequestration potential.

\section{CONCLUSIONS}

Our study focuses on the phytolith and PhytOC contents of different plant communities and their constituent species on a climate gradient in the semi-arid steppe region of the Mongolian Plateau. Our results show that the phytolith and PhytOC contents differ among plant species, and that climatic factors affect phytolith and PhytOC production rates of steppe communities mainly through affecting plant production, whereas their effects on the phytolith and PhytOC contents in plants are relatively small. Our results also demonstrate that plant aboveground biomass (AGB) and PhytOC content are strongly associated with the current-year climate and bioavailable $\mathrm{Si}$ content in the soil, while the variation in plant belowground biomass (BGB) 
and PhytOC content across sites was more correlated with the long-term mean values of climatic and soil factors across the sites, reflecting the perenniality of the belowground part of steppe plants. More studies are warranted to quantify annual PhytOC production from plant belowground part with the effects of plant perenniality incorporated.

\section{ACKNOWLEDGEMENTS}

The work was supported by National Natural Science Foundation of China (31670454), the Ministry of Science and Technology of China (2015BAC02B04) and the Department of Science and Technology of Inner Mongolia Autonomous Region (201501007).

\section{CONFLICT OF INTEREST}

None declared.

\section{AUTHOR CONTRIBUTIONS}

FYL and LQ conceptualized the study and designed the methodology; LQ, TS, YG and XG did the field survey, sample collection and laboratory analysis; LQ analyzed the data and wrote up the first manuscript with inputs from FYL; all authors provided feedback and helped shape the final manuscript.

\section{REFERENCES}

Bai, Y., Han, X., Wu, J., Chen, Z., \& Li, L. (2004). Ecosystem stability and compensatory effects in the Inner Mongolia grassland. Nature, 431, 181-184. https://doi.org/10.1038/nature02850

Bai, Y., Wu, J., Xing, Q., Pan, Q., Huang, J., Yang, D., \& Han, X. (2008). Primary production and rain use efficiency across a precipitation gradient on the Mongolia Plateau. Ecology, 89, 2140-2153. https://doi.org/10.1890/07-0992.1

Bartoli, F., \& Wilding, L. P. (1980). Dissolution of biogenic opal as a function of its physical and chemical properties. Soil Science Society of America Journal, 44, 873-878. https://doi.org/10.2136/sssaj1980.03615995004400040043x

Berner, R. A. (1992). Weathering, plants, and the long-term carbon cycle. Geochimica et Cosmochimica Acta, 56, 3225-3231. https://doi.org/10.1016/ 0016-7037 (92)9030-8

Blecker, S. W., Mcculley, R. L., Chadwick, O. A., \& Kelly, E. F. (2006). Biologic cycling of silica across a grassland bioclimosequence. Global Biogeochemical Cycles, 20, 1-11. https://doi.org/10.1029/2006GB002690

Chai, X., Liang, C., Liang, M., Han, W., Li, Z. Y., Miao, B., ...Wang, L. (2014). Seasonal dynamics of belowground biomass and productivity and potential of carbon sequestration in meadow steppe and typical steppe in Inner Mongolia, China. Acta Ecologica Sinica, 34, 5530-5540. https://doi.org/10.584/ stxb201301190118

Chen, C., Huang, Z., Jiang, P., Chen, J., \& Wu, J. (2018). Belowground phytolith- occluded carbon of monopodial bamboo in China: an overlooked carbon stock. Frontiers in Plant Science, 6, 1615. https://doi.org/10.3389/fpls.2018.01615

Clarkson, D. T., \& Hanson, J. B. (1980). The mineral nutrition of higher plants. Annual Review of Plant Biology, 31, 239-298. https://doi.org/10.1146/annurev.pp. 31.060180.001323

Conley, \& Daniel, J. (2002). Terrestrial ecosystems and the biogeochemical silica cycle. Global Biogeochemical Cycles, 16, 68-1-68-8. https://doi.org/10.1029/ 2002GB001894

Dai, C., Kang, M., Ji, W., \& Jiang, Y. (2012). Responses of underground productivity to biomass and environmental factors in Xilingol grassland, Inner Mongolia. Chinese Journal of Grassland, 34, 54-60. https://doi.org/1673-5021(2012) 03-0054-07 
Easterling, D. R., Meehl, G. A., Parmesan, C., Changnon, S. A., Karl, T. R., \& Mearns, L. O. (2000). Climate extremes: observations, modeling, and impacts. Science, 298, 2068-2074. https://doi.org/10.1126/science.289.5487.2068

Epstein, E. (1994). The anomaly of silicon in plant biology. Proceedings of the National Academy of Sciences of the United States of America, 91, 11-17. https://doi.org/10.1073/pnas.91.1.11

Epstein, E. (2009). Silicon: its manifold roles in plants. Annals Applied Biology, 155, 155-160. https://doi.org/10.1111/j.1744-7348.2009.00343.x

Fraysse, F., Pokrovsky, O. S., Schott, J., \& Meunier, J. D. (2009). Surface chemistry and reactivity of plant phytoliths in aqueous solutions. Chemical Geology, 258, 197-206. https://doi.org/10.1016/j.chemgeo.2008.10.003

Hodson, M. J., White, P. J., Mead, A., \& Broadley, M. R. (2005). Phylogenetic variation in the silicon composition of plants. Annals of Botany, 96, 1027-1046. https://doi.org/10.1093/aob/mci255

Hou, X., Ji, L., \& Wang, Z. (2014). Response of net primary productivity and C accumulation of plant communities in desert steppe and semiarid steppe with different land use types during two hydrologically contrastiong growing seasons. Acta Ecologica Sinica, 34, 6256-6264. https://doi.org/10.5846/stxb201301310206

Ji, Z., Yang, X., Song, Z., Liu, H., Liu, X., Qiu, S., ...Zhang, X. (2018). Silicon distribution in meadow steppe and typical steppe of northern China and its implications for phytolith carbon sequestration. Grass and Forage Science, 73, 482-492. https://doi.org/10.1111/gfs.12316

Jones, L. H. P., \& Milne, A. A. (1965). Studies of silica in the oat plant. Plant and Soil, 23, 79-96. https://doi.org/10.1007/BF01347875

Knapp, A. K., \& Smith, M. D. (2001). Variation among biomes in temporal dynamics of aboveground primary production. Science, 291, 481-484. https://doi.org/ 10.1126/science.291.5503.481

Li, Z., Song, Z., Parr, J. F., \& Wang, H. (2013a). Occluded C in rice phytoliths: implications to biogeochemical carbon sequestration. Plant and Soil, 370, 615-623. https://doi.org/10.1007/s11104-013-1661-9

Li, Z., Song, Z., \& Li, B. (2013b). The production and accumulation of phytolithoccluded carbon in Baiyangdian reed wetland of China. Applied Geochemistry, 37, 117-124. https://doi.org/10.1016/j.apgeochem.2013.07.012

Ma, J. F., \& Yamaji, N. (2006). Silicon uptake and accumulation in higher plants. Trends in Plant Science, 11, 392-397. https://doi.org/10.1016/j.tplants. 2006.06.007

Ma, W., Fang, J., Yang, Y., \& Mohammat, A. (2010). Biomass carbon stocks and their changes in northern China's grasslands during 1982-2006. Science China-life Sciences, 53, 841-850. https://doi.org/10.1007/s11427-010-4020-6

Pan, W., Song, Z., Liu, H., Mueller, K., Yang, X., Zhang, X., ...Wang, H. (2017). Impact of grassland degradation on soil phytolith carbon sequestration in Inner Mongolia steppe of China. Geoderma, 308, 86-92. https://doi.org/10.1016/ j.geoderma.2017.08.037

Parr, J. F., Sullivan, L. A., Chen, B., Ye, G., \& Zheng, W. (2010). Carbon bio-sequestration within the phytoliths of economic bamboo species. Global Change Biology, 16, 2661-2667. https://doi.org/10.1111/j.13652486.2009. 02118.x

Parr, J. F., Sullivan, L. A., \& Quirk, R. (2009). Sugarcane phytoliths: encapsulation and sequestration of a long-lived carbon fraction. Sugar Tech, 11, 17-21. https:// doi.org/10.1007/s12355-009-0003-y

Parr, J. F., Dolic, V., Lancaster, G., \& Boyd, W. E. (2001). A microwave digestion method for the extraction of phytoliths from herbarium specimens. Review of Palaeobotany and Palynology, 116, 203-212. https://doi.org/10.1016/ S0034-6667(01)00089-6 
Parr, J. F., \& Sullivan, L. A. (2005). Soil carbon sequestration in phytoliths. Soil Biologyand Biochemistry, 37, 117-124. https://doi.org/10.1016/ j.soilbio.2004.06.013

Parr, J. F., \& Sullivan, L. A. (2011). Phytolith occluded carbon and silica variability in wheat cultivars. Plant and Soil, 342, 165-171. https://doi.org/ 10.1007/s11104-010-0680-z

Parr, J. F., \& Sullivan, L. A. (2014). Comparison of two methods for the isolation of phytolith occluded carbon from plant material. Plant and Soil, 374, 45-53. https://doi.org/10.1007/s11104-013-1847-1

Qi, L., Li, F. Y., Huang, Z., Jiang, P., Baoyin, T., \& Wang, H. (2016). Phytolith-occluded organic carbon as a mechanism for long-term carbon sequestration in a typical steppe: the predominant role of belowground productivity. Science of Total Environment, 577, 413-417. https://doi.org/10.1016/j.scitotenv.2016.10.206

Ru, N., Yang, X., Song, Z., Liu, H., Hao, Q., Liu, X., \& Wu, X. (2018). Phytoliths and phytolith carbon occlusion in aboveground vegetation of sandy grasslands in eastern Inner Mongolia, China. Science of Total Environment, 625, 1283-1289. https:// doi.org/10.1016/j.scitotenv.2018.01.055

Schaller, J., Brackhage, C., Paasch, S., Brunner, E., Baucker, E., \& Dudel, E. G. (2013). Silica uptake from nanoparticles and silica condensation state in different tissues of Phragmites australis. Science of Total Environment, 442, 6-9. https://doi.org/10.1016/j.scitotenv.2012.10.0166.199

Scurlock, J. M. O., \& Hall, D. O. (2010). The global carbon sink: a grassland perspective. Global Change. Biology, 4, 229-233. https://doi.org/10.1046/j.1365-2488.00151.x

Scurlock, J. M. O., Johnson, K. R., \& Olson, R. J. (2002). Estimating net primary productivity from grassland biomass dynamics measurements. Global Change Biology, 8, 736-753. https://doi.org/10.1046/j.13652486.2002.00512.x

Song, Z., Liu, H., Stromberg, C. A. E., Yang, X., \& Zhang, X. (2017). Phytolith carbon sequestration in global terrestrial biomes. Science of Total Environment, 603, 502-509. https://doi.org/10.1016/j.scitotenv.2017.06.107

Song, Z., Liu, H., Si, Y., \& Yin, Y. (2012a). The production of phytoliths in China's grasslands: implications to the biogeochemical sequestration of atmospheric $\mathrm{CO}_{2}$. Global Change Biology, 18, 3647-3653. https://doi.org/10.1111/gcb.12017

Song, Z., Wang, H., Strong, P. J., Li, Z., \& Jiang, P. (2012b). Plant impact on the coupled terrestrial biogeochemical cycles of silicon and carbon: implications for biogeochemical carbon sequestration. EarthScience Reviews, 115, 319-331. https://doi.org/10.1016/j.earscirev.2012.09.006

Stromberg, C. A. E., Stilio, V. S. D., \& Song, Z. (2016). Functions of phytoliths in vascular plants: an evolutionary perspective. Functional Ecology, 30, 1286-1297. https://doi.org/10.1111/1365-2435.12692

Walkley, A. J., \& Black, I. A. (1934). An examination of the degtjareff method for determining soil organic matter, and a proposed modification of the chromic acid titration method. Soil Science, 37, 29-38. https://doi.org/10.1097/ 00010694-193401000-00003

Yang, J., Li, Y., Huang, Z., Jiang, P., Xiang, T., \& Ying, Y. (2014). Determination of phytolith-occluded carbon content using alkali dissolution- spectrophotometry. Chinese Journal of Analytical Chemistry, 42, 1389-1390. https://doi.org/10.11895/j.issn.02533820.131190

Yang, X., Song, Z., Liu, H., Zwieten, L. V., Song, A. L., Li, Z., .. Wang, H. (2018). Phytolith accumulation in broadleaf and conifer forests of northern China: implications for phytolith carbon sequestration. Geoderma, 312, 36-44. https://doi.org/10.1016/j.geoderma.2017.10.005

Zhang, X., Song, Z., Hao, Q., Wang, Y., Ding, F., \& Song, A. (2019). Phytolith-occluded carbon storages in forest litter layers in southern China: implications for evaluation of long-term forest carbon budget. Frontiers in Plant Science, 10, 581. https://doi.org/10, 581. doi: 10.3389/fpls.2019.00581 
Zuo, X., \& Lu, H. (2011). Carbon sequestration within millet phytoliths from dry-farming of crops in China. Chin. Science Bulletin, 56, 3451-3456. https://doi.org/10.1007/s11434-011-4674-x

\section{FIGURE LEGENDS}

FIG. 1. The phytolith content in the above- and belowground parts of dominant plants in the desert steppe (A), dry typical steppe (B) and wet typical steppe (C) in Inner Mongolia. Species are ordered according to their relative biomass in steppe communities. Different lowercase letters indicate significant differences in the above- or the belowground plant part among species $(P<0.05)$.

FIG. 2 .The PhytOC content in the above- and belowground parts of dominant plants in the desert steppe (A), dry typical steppe (B) and wet typical steppe (C) in Inner Mongolia. Species are ordered according to their relative biomass in steppe communities. Different lowercase letters indicate significant differences in the above- or the belowground plant part among species $(P<0.05)$.

FIG. 3 The phytolith content (A) and PhytOC content (B) in the above- and belowground parts of steppe communities in Inner Mongolia. No significant differences are detected for either above- or belowground part among steppe types $(P<0.05)$.

FIG.1.FIG.2.FIG.3

\section{TABLES}

TABLE 1. The soil bulk density (BD), moisture, $\mathrm{pH}$, organic carbon (SOC) and bioavailable Si contents at the three steppe sites

\begin{tabular}{lcllllll}
\hline Sites & $\mathrm{BD}\left(\mathrm{g} \mathrm{cm}^{-3}\right)$ & $\begin{array}{l}\text { Moisture } \\
(\%)\end{array}$ & $\begin{array}{l}\text { Moisture } \\
(\%)\end{array}$ & $\mathrm{pH}$ & $\begin{array}{l}\text { SOC }(\mathrm{g} \\
\left.\mathrm{kg}^{-1}\right)\end{array}$ & $\begin{array}{l}\text { SOC }(\mathrm{g} \\
\left.\mathrm{kg}^{-1}\right)\end{array}$ & $\begin{array}{l}\text { Bioavailable } \\
\mathrm{Si}^{\left(\mathrm{mg} \mathrm{kg}^{-1}\right)}\end{array}$ \\
$\begin{array}{l}\text { Desert } \\
\text { steppe }\end{array}$ & $1.30 \mathrm{~b}$ & $2.79 \mathrm{c}$ & $8.77 \mathrm{a}$ & $8.77 \mathrm{a}$ & $8.77 \mathrm{a}$ & $0.90 \mathrm{c}$ & $0.32 \mathrm{a}$ \\
$\begin{array}{l}\text { Dry } \\
\text { typical }\end{array}$ & $1.32 \mathrm{~b}$ & $14.71 \mathrm{~b}$ & $8.05 \mathrm{a}$ & $8.05 \mathrm{a}$ & $8.05 \mathrm{a}$ & $2.81 \mathrm{~b}$ & \\
$\begin{array}{l}\text { steppe } \\
\begin{array}{l}\text { Wet } \\
\text { typical } \\
\text { steppe }\end{array}\end{array}$ & $1.49 \mathrm{a}$ & $21.32 \mathrm{a}$ & $7.51 \mathrm{~b}$ & $7.51 \mathrm{~b}$ & $7.51 \mathrm{~b}$ & $3.12 \mathrm{a}$ & $0.27 \mathrm{a}$ \\
\hline
\end{tabular}

Note: different letters indicate significant difference among steppe types at $P<0.05$.

TABLE2. The aboveground (AGB) and belowground biomass (BGB) ( $\mathrm{kg} \mathrm{ha}^{-1}$; mean $\left.\pm \mathrm{SE}\right)$ of the three major steppe communities and their major composing species in Inner Mongolia. (A/B refers to the AGB/BGB ratio)

\begin{tabular}{lllll}
\hline Types & Species name & AGB & BGB & A/B \\
Desert steppe & Stipa klemenzii & $256.89 \pm 61.11$ & $1511.11 \pm 359.45$ & 0.17 \\
& Cleistogenes songorica & $83.00 \pm 42.06$ & $237.14 \pm 120.17$ & 0.35 \\
& Salsola collina & $73.22 \pm 58.74$ & $95.09 \pm 76.28$ & 18.23 \\
& Scorzonera divaricata & $21.67 \pm 21.67$ & $4.47 \pm 4.47$ & 4.85 \\
& Allium mongolicum & $18.11 \pm 8.71$ & $95.32 \pm 45.82$ & 0.19 \\
& Caragana pygmaea & $17.67 \pm 15.71$ & $0.97 \pm 0.86$ & 0.77 \\
& Carex korshinskyi & $13.78 \pm 2.41$ & $52.99 \pm 9.25$ & 0.26 \\
& Allium bidentatum & $8.44 \pm 7.00$ & $140.74 \pm 116.64$ & 0.06 \\
& Sum of major species & 492.78 & $2137.83^{\#}$ & \\
Community & 562.27 & $4227.99^{\#}$ & \\
& Leymus chinensis & $404.68 \pm 40.26$ & $586.49 \pm 132.52$ & 0.69
\end{tabular}




\begin{tabular}{lllll} 
& Stipa krylovii & $394.12 \pm 231.38$ & $985.31 \pm 227.18$ & 0.40 \\
Stipa grandis & $352.92 \pm 175.27$ & $840.29 \pm 163.22$ & 0.42 \\
Cleistogenes squarrosa & $132.59 \pm 62.40$ & $301.34 \pm 20.67$ & 0.44 \\
Agropyron michnoi & $72.67 \pm 72.67$ & $117.20 \pm 18.54$ & 0.62 \\
Carex korshinskyi & $14.32 \pm 14.32$ & $95.48 \pm 1.08$ & 0.15 \\
Artemisia frigida & $7.16 \pm 7.16$ & $3.44 \pm 0.66$ & 2.08 \\
& Sum of major species & 1378.64 & 2929.55 & \\
& Community & 1471.99 & 8639.89 & \\
Wet typical steppe & Stipa grandis & $553.48 \pm 168.32$ & $1777.45 \pm 393.71$ & 0.31 \\
& Cleistogenes squarrosa & $303.37 \pm 122.25$ & $864.56 \pm 316.41$ & 0.33 \\
& Leymus chinensis & $200.39 \pm 83.52$ & $301.21 \pm 113.58$ & 0.67 \\
Sum of major species & 1057.24 & 2943.22 & \\
Community & 1120.09 & 8643.74 & \\
\hline
\end{tabular}

\# The sum of the BGB of major species is the BGB in top $20 \mathrm{~cm}$ soil layer determined in this study, while the BGB of community is estimated based on the BGB in the top $20 \mathrm{~cm}$ soil layer and the belowground biomass profile determined in previous studies for these communities (Chai et al. 2014; Hou et al., 2014).

TABLE 3. Estimation of plant aboveground biomass (AGB) and net primary productivity (ANPP), belowground biomass (BGB) and net primary productivity (BNPP), and biomass-weighted community mean PhytOC content, stock and production flux (mean $\pm \mathrm{SE}$ ) of the three steppe types in Inner Mongolia.

\begin{tabular}{llllll}
\hline Steppe types & $\begin{array}{l}\text { PhytOC content }\left(\mathrm{g} \mathrm{kg}^{-1}\right) \\
\text { aboveground }\end{array}$ & $\begin{array}{l}\text { PhytOC content }\left(\mathrm{g} \mathrm{kg}^{-1}\right) \\
\text { belowground }\end{array}$ & $\begin{array}{l}\mathrm{AGB}=\mathrm{ANPP} \\
\left(\mathrm{kg} \mathrm{ha}^{-1} \mathrm{yr}\right)\end{array}$ & $\begin{array}{l}\text { BGB } \\
(0-70 \mathrm{~cm})\end{array}$ & $\begin{array}{l}\text { BNPP* } \\
\left(\mathrm{kg} \mathrm{ha}^{-1}\right.\end{array}$ \\
Desert steppe & $0.68 \pm 0.12 \mathrm{a}$ & $1.11 \pm 0.26 \mathrm{a}$ & $562.65 \pm 49.28 \mathrm{~b}$ & $4227.99 \pm 456.20 \mathrm{~b}$ & 7964 \\
Dry typical steppe & $0.48 \pm 0.01 \mathrm{a}$ & $0.72 \pm 0.08 \mathrm{a}$ & $1471.99 \pm 110.82 \mathrm{a}$ & $8639.89 \pm 543.77 \mathrm{a}$ & 13446 \\
Wet typical steppe & $0.59 \pm 0.08 \mathrm{a}$ & $1.02 \pm 0.07 \mathrm{a}$ & $1120.09 \pm 52.98 \mathrm{a}$ & $8643.74 \pm 491.55 \mathrm{a}$ & 17955 \\
\hline
\end{tabular}

Note: The range of BNPP is estimated based on the BNPP and the turn-over rate of belowground biomass determined in several studies on the Mongolian steppes (Chai et al., 2014; Hou et al., 2014) and the measurement of above- and belowground biomass $(0-70 \mathrm{~cm})$ in this experiment. Different lowercase letters indicate significant differences among steppe types at $P<0.05$ (Duncan's test).

\section{DATA AVAILABILITY STATEMENT}

Data will be available from the Dryad Digital Repository.

\section{Hosted file}

Figure.docx available at https://authorea.com/users/346008/articles/472111-phytolithoccluded-carbon-sequestration-potential-in-three-major-steppe-types-along-a-

precipitation-gradient-in-northern-china 